\title{
Correlation between Car Accident and Car Color for Intelligent Service
}

\author{
Seong-yoon Shin \\ Department of Computer Information Engineering, \\ Kunsan National University \\ (s3397220@kunsan.ac.kr)
}

\author{
Sangwon Lee \\ Division of Information and Electronic \\ Commerce (Institute of Convergence and \\ Creativity), Wonkwang University \\ (sangwonlee@wku.ac.kr)
}

In designing Intelligent Traffic Systems, it should be necessary to consider telecommunications, appearance, environment, auxiliary functions, safety, and so on. Also, in choosing a car, a consumer considers those properties. This paper tried to elucidate the fact that car color has a very significant meaning for car safety when administrating intelligent traffic services and making car-purchasing decision. We first studied on occurrence probability of car accident according to car color that has something to do with car safety. Then, we studied on the concepts of advancing color and receding color. Advancing color causes less accidents since the color looks closer than it actually is. And receding color causes more accidents since the color looks farther than it actually is. And we classified car colors into eight classes and assign their ranking to each class, considering the number of car accidents. We tried to verify our research by use of telephone questionnaire for residents in Kunsan, Republic of Korea.

Received : December 18, 2013 Accepted : December 24, 2013

Type of Submission : Concise Paper Corresponding author : Sangwon Lee

\section{Introduction}

Intelligent Traffic Systems involve an efficient and effective interaction between all of its components such as drivers, pedestrians, traffic management systems, and public transportation. Intelligent traffic systems provide various in- telligent services (e.g. Big Data Analysis or Data Mining) (Baek et al., 2010; Kim et al., 2010; Cho et al., 2011; Yu et al., 2013) by aiming to make full use of car properties. Especially in car safety, the car color is a very important factor and should be considered in designing and implementing intelligence services as well

* This paper was supported by Wonkwang University in 2013. 
as in purchasing a car.

Let us assume that a customer considers purchasing a car. There are five major factors in selecting a car. We first of all consider its use for private, family, and freight. There is no necessity for buying a big or expensive car for individual commuting. Secondly, we consider its price with guarantee condition, installment plan, and so forth. Thirdly, we analyze the price and performance of the selected car. The analysis could be supported by preference reports or expert opinions on that car. Fourthly, we try to drive and operate the car. This try is a good factor in experiencing the car. Fifthly, after these four considerations, we check the price again. In the ear of high oil price, we never even dream of driving a car. So, we choose a car after checking its average mileage a liter. And we also consider whether we will drive it in the town or on the high ways as well as on the paved road or on the unpaved road. Lastly, we consider its design and color that we like. However, we should know that the selected color is closely related with car accident.

Since car color has something to do with car accident, the relationship between accident and color is a very important factor. There are hundreds of car body colors as car flame. However, only eight colors are widely used. We limit 8 car colors in order to express relationship between car accident and car color. In Korea, deep colors like black were widely used in the days when cars were rare. In these days of
Korea, light colors like silver, gold, and white are largely used. Lately, cars in white, gold (or yellow), and silver are increasing more and more. What color of cars was used the most 2 3 years ago in Korea? It is not difficult to know the colors. In Korea, black, white, and silver are most widely used. It would be so since many Koreans like quite tones. But, from the last 2011, colors of cars have been changing little by little. Small-sized cars show this phenomenon remarkably rather than large-sized ones. Golden or yellowish colors as well as pinkish ones have been increasing. In fact, sales volume of yellowish and pinkish cars actually increased. Even though this phenomenon shows the expressions of personality and tendency of car owners, it is considered to have anything to do with car accident.

This paper studies on the rate or ranking according to car colors in Kunsan, Republic of Korea. Session 2 shows related works on relationship between car color and car accident and Session 3 checks concepts of advancing color and receding color. In Session 4, we perform an experiment for relationship between car color and car accident. Lastly we make conclusions and further studies in Session 5.

\section{Related Works}

The damage extent of car accident and social cost are as follows. According to data of Korea Road Traffic Authority in <Table 1>, 
there are 897,271 car accidents in 2011 with killing 5,229 and wounding 1,434,786 (seriously wounded 173,809, slightly wounded 935,449, and wounded reported 325,528.

$<$ Table 1> Year-on-Year Traffic Accident Overview

(Unit: Person, \%)

\begin{tabular}{|l|r|c|}
\hline \multicolumn{1}{|c|}{ Basic Year } & \multicolumn{1}{c|}{2011} & 2010 \\
\hline Number of Cases & 897,271 & 979,307 \\
\hline Increasing/Decreasing Number & $-82,036$ & - \\
\hline Increasing/Decreasing Rate & -8.4 & - \\
\hline Killed & 5,229 & 5,505 \\
\hline Increasing/Decreasing Number & -276 & - \\
\hline Increasing/Decreasing Rate & -5 & - \\
\hline Injured & $1,434,786$ & $1,533,609$ \\
\hline Increasing/Decreasing Number & -98.823 & - \\
\hline Increasing/Decreasing Rate & -6.4 & - \\
\hline
\end{tabular}

Source : KoROAD.

The yearly cost of road accidents in Korea increases to 13 trillion won. KoRoad said the social cost that is caused by car accident of 2010. The cost of 2010 is $12,959.9$ billion won, which is 1.1 percent of GDP or 6.4 percent of a national budget of Korea. The cost of 2009 increases 10 percent (118.24 billion won) more than that of 2009. This scale is 1.1 percent of GDP 1172.8034 trillion won or 6.4 percent of Korea national budget 201.2835 trillion won. The Shin et al. (Shin et al., 2013) shows the relationship between car color and car accident on the basis of chromatic aberration. But, we perform an experiment for 138 cars by use of seven colors. It is not easy to show the relationship since the number of data is very small. The Furness et al. (Furness et al., 2003) investigated the effect of car color on the risk of a serious injury from a crash, using a population based case control study designed to identify and quantify modifiable risk factors. According to Ansah et al. (Ansah et al., 2010), over the years, the concern of many, consumers and insurance companies alike, has been geared towards the contribution of vehicle color to the risk of crash. Consequently, there is a need to provide sufficient scientific evidence to back consumers in selecting the appropriate vehicle color that enhances their safety on the road. Very little research has been conducted to study whether vehicle color may have an effect on motor vehicle crash. Particularly, scientific studies to determine the relationship between vehicle color and crash risks have been scarcely investigated (Newstead, et al., 2007). Many studies have investigated the relationship between color and visibility (FEMA, et al., 2009) and most of them have focused on reflectivity of sign visibility (Anders et al., 2000; Hawkins et al., 2000; Gates et al., 2004).

\section{Concepts of Car Color}

The retraction index of color and focusing function of our eyes make location of an object look differently according to color. In chromatics, this phenomenon is called as Chromatic Aberration. Chromatics is a science that determines the essence of chromatic phenomena and researches on mutual relationships between color and human living. Let us assume that a black car and a golden car stand in the same location. 
The black car looks smaller as if it would be far from its real location. Meanwhile, the golden car looks closer than it really is. Since the retraction index of light is small in case of gold chromatic aberration, the image is focused behind the retina. Then, the eyeball inflates crystalline lens in order to focus the image on the retina. At this moment, the crystalline lens inflates and becomes convex lens. So, the golden car looks closer than it really is. On the contrary, the black car looks farther than it really is. In addition, there are advanced color and receding color in the world. An advanced color means the color that looks closer although it really is farther. A receding color means the color that looks farther although it really is closer. In this paper, we assume that the concept of chromatic aberration is the same as that of advanced color and receding color.

\subsection{Advancing Color}

An advanced color means the color that looks closer although it really is farther. Warm colors such as red or yellow belong to the advanced color. In other words, advanced color is the color that looks about to stick out forward rather than background color. Colors with high brightness and high chroma look closer although they really are farther. We can easily find out the effect if colors are arranged by stages. Advanced color is also called expansive image. Advanced colors are yellow (gold), brown (chestnut), black, and so on. In $<$ Figure $1>$, they look larger than other colors with expansive property.
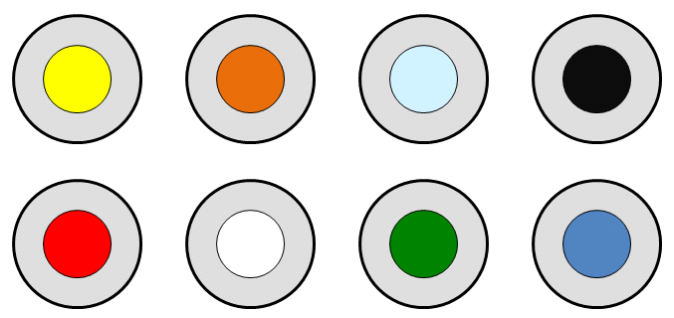

$<$ Figure 1> Advanced Colors (Order : Left-Top $\rightarrow$ Right-Top, Left-Bottom $\rightarrow$ Right-Bottom)

\subsection{Receding Color}

A receding color means the color that looks farther although it really is closer. Colors have low brightness and low chroma. We can easily find out the effect if colors are arranged by stages. Receding color is also called contractive image. Receding colors are green, blue, and so on. Adversely, receding color is the color that looks about to draw back backward in $<$ Figure $2>$.
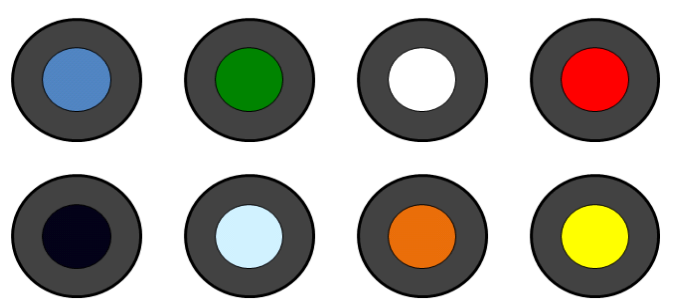

<Figure 2> Receding Colors (Order : Left-Top $\rightarrow$ Right-Top, Left-Bottom $\rightarrow$ Right-Bottom)

Warm colors such as yellow and red are advanced colors since they look about to stick out forward rather than cold colors such as blue 
and blue-green. Cold colors are receding colors since they look farther. Chromatic colors tend to advance rather than achromatic ones. In case of dark backgrounds, lighter colors are more advanced. But, in case of bright backgrounds, darker colors are more advanced. Warm colors are more advanced than cold ones. Bright colors are more advanced than dark ones. Colors with high chroma are more advanced than those with low chroma. Although white, red, black, and silver are cold or warm colors in <Figure $1>$ and $<$ Figure 2>, they tend to look different from the standard of chromatic or achromatic color. But, from the enamel color characteristic of real cars, the order of figure is right. Enamel color is quicker drying than oil paint. And its Dry-PaintFilm is smoother and its gloss is more fluent.

\section{Experiment : Rate of Accident and Ranking according to Car Color}

In choosing a car, most of people preferentially consider the usage and price of the car among various conditions such as option, installment condition, and so on. But, we should know that color is an important factor to be considered. Car color has something to do with car accident and is a very important factor. For safety, it is better to choose expansive color with bright tone than to choose contractive with dark tone. So as to check relationship between car color and car accident, we should choose widely-used colors. $<$ Figure $3>$ shows the arrangement of representative car colors. The colors are classified into eight colors from blue to yellow (gold). Seven colors of them go match car colors. These eight colors represent a lot of colors. For instance, the colors with red tone are commonly called 'red.' The detailed colors are named by car manufactures so we leave the names out of discussion. (a)

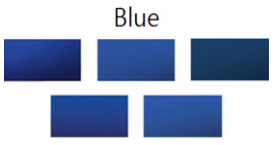

(b)

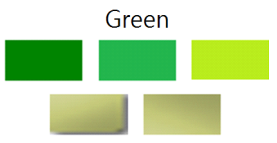

(c)

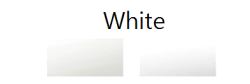

(d)

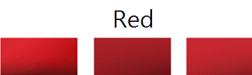

(e)

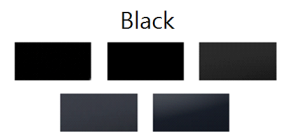

(f)

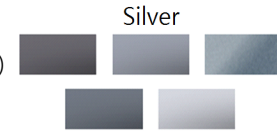

Brown(Chestnut)

(g)

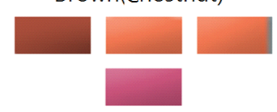

(h)

Yellow(Gold)
$<$ Figure 3> Eight Car Colors

Now, we show four practical examples with the above-mentioned three assumptions, five definitions, and nine rules with four ones to extract objects and associations and five ones to extract entities and relationships.

We performed an experiment with crapped 10-old-year cars in Kunsan. We checked scrapped cars in various locations such as junkyards of local the government for research on colors of car accidents. But there were no materials related to our research concerns. So, we should check colors of scrapped cars or perform phone interviews with individuals for ourselves. Table 2 shows the questionnaire performed in phone 
or direct interviews.

\section{<Table 2> Questionnaire on Car Accident}

\begin{tabular}{|l|l|}
\hline \multicolumn{1}{|c|}{ Items of Questiionnaire } & \multicolumn{1}{|c|}{ Remarks } \\
\hline Is there an accidentor not? & Yes or No \\
\hline $\begin{array}{l}\text { Which is the accident car, } \\
\text { sedan or van? }\end{array}$ & Sedan of Van \\
\hline $\begin{array}{l}\text { How many accidents do you } \\
\text { have? }\end{array}$ & One to ten \\
\hline $\begin{array}{l}\text { What color of the accident } \\
\text { car is? }\end{array}$ & $\begin{array}{l}\text { Blue, Green, White, Red, } \\
\text { Black, Silver, Brown, and } \\
\text { Yellow (Gold) }\end{array}$ \\
\hline $\begin{array}{l}\text { ls there any relation } \\
\text { between the accident car } \\
\text { and its color? }\end{array}$ & Yes or No \\
\hline
\end{tabular}

500 persons responded to the 1123 questionnaires. We checked accident rates and ranking for each color by use of 500 responses. We got a result like $<$ Table $3>$.

$<$ Table 3> The Number of Car Accidents

\begin{tabular}{|c|c|c|}
\hline Accident & Yes & No \\
\hline The number of cars & 500 & 623 \\
\hline Percentage & 44.5 & 55.5 \\
\hline
\end{tabular}

Our questionnaire includes an item in order to check the type of accident cars, sedan or van $<$ Table $4>$. The sedan is used to transport persons, and the van is used to transport freights.

$<$ Table 4> The Type of Car Accidents

\begin{tabular}{|c|c|c|}
\hline Type & Sedan & Van \\
\hline The number of cars & 324 & 176 \\
\hline Percentage & 64.8 & 35.2 \\
\hline
\end{tabular}

There are cars with at most 10 accidents.
Some cars have no accident. We calculate the number of accidents redundantly for each car. In addition, we researched on the color of all accident cars. $<$ Table 5> shows the preference of car color. Silver has the highest preference and brown (chestnut) is the lowest one.

$<$ Table 5> The Preference of Car Colors

\begin{tabular}{|c|c|c|c|}
\hline Car Color & $\begin{array}{c}\text { The Number } \\
\text { of Vehicle }\end{array}$ & $\begin{array}{c}\text { Preference } \\
\text { of Color }\end{array}$ & $\begin{array}{c}\text { Preference } \\
\text { Rank }\end{array}$ \\
\hline Blue & 42 & 8.4 & 4 \\
\hline Green & 36 & 7.2 & 6 \\
\hline White & 104 & 20.8 & 2 \\
\hline Red & 38 & 7.6 & 5 \\
\hline Black & 96 & 19.2 & 3 \\
\hline Silver & 114 & 22.8 & 1 \\
\hline Brown (Chestnut) & 34 & 6.8 & 8 \\
\hline Yellow (Gold) & 36 & 7.2 & 6 \\
\hline Total & 500 & 100 & - \\
\hline
\end{tabular}

$<$ Table 6> shows the number of car accidents according to car colors. The ratio of accident cars is calculated with the number of car accidents divided by the number of cars. The more the ratio is, the more the accidents are. In $<$ Table 6>, the rank of blue is 1 since it is a receding color. The rank of yellow (gold) is 8 so its probability of car accident is the least. Since yellow has no chromatic aberration, it is focused on the retina when entering eyes. Yellow has properties to expand on the retina like ink and look larger among colors. So, for drivers, it is used as hats, raincoats, backpacks of preschool and elementary school. The descending order of accident occurrence probabilities is blue, green, 
white, red, black, silver, and yellow (gold).

$<$ Table 6> Ratio of Car per Accident and Rank

\begin{tabular}{|c|c|c|c|c|}
\hline Car Color & $\begin{array}{c}\text { The Number } \\
\text { of Cars }\end{array}$ & $\begin{array}{c}\text { The Number } \\
\text { of Accidents }\end{array}$ & $\begin{array}{c}\text { Ratio of } \\
\text { Accidents } \\
\text { per Car }\end{array}$ & Rank \\
\hline Blue & 42 & 145 & 345.24 & 8 \\
\hline Green & 36 & 119 & 330.56 & 7 \\
\hline White & 104 & 301 & 289.42 & 6 \\
\hline Red & 38 & 105 & 276.32 & 5 \\
\hline Black & 96 & 259 & 269.79 & 4 \\
\hline Silver & 114 & 274 & 240.35 & 3 \\
\hline Brown (Chestnut) & 34 & 80 & 235.29 & 2 \\
\hline Yellow (Gold) & 36 & 76 & 211.11 & 1 \\
\hline Total & 500 & 1,359 & - & - \\
\hline
\end{tabular}

In $<$ Table $7>, 309$ responders (79 percent) think that there is relationship between car color and car accident. The number of the responders is four times as many as that of rest (21 percent) who does not think any relationship between car color and car accident. Consequently, most of drivers think that color has something to do with accident.

$<$ Table 7> Relationship between Car Color and Car Accident

\begin{tabular}{|c|c|c|}
\hline Relationship & Sedan & Van \\
\hline Persons & 395 & 105 \\
\hline Percentage & 79 & 21 \\
\hline
\end{tabular}

\section{Conclusions}

For traffic safety in making car-purchasing decision or administrating Intelligence Traffic Systems, color should be considered on the pref- erential basis before other options. As we already performed telephone questionnaire for citizens in Kunsan in order to research on car accidents and their car colors, the results are as follows. Advanced colors have low probability of car accident since they look closer than they really are. On the contrary, receding colors have high probability of car accident since they look farther than they really are. And we classified car colors into eight ones such as black, white, blue, green, silver, red, brown (chestnut), and yellow (gold). After considering the probability of car accidents, we concluded that the descending order is blue, green, white, red, black, silver, brown (chestnut), and yellow (gold). And we proposed the usage of cars, the ratio of sedan versus van, the preference of car color, and the ratio of car color and car accident. However, although we found out the fact that car color has something to do with car accident in the field of safety, more consideration of other properties should be researched further.

\section{References}

Anders, R. L., "On-road Investigation of Fluorescent Sign Colors to Improve Conspicuity," Virginia Polytechnic Institute and State University, 2000.

Ansah, O. and S. Osei, "Investigation of the Relationship between Vehicle Color and Safety," Master of Science, University of Dayton, Department of Civil Engineering, 2010.

Baek, W. and N. Kim, "A Case Study on Forecasting Inbound Calls of Motor Insurance 
Company Using Interactive Data Mining Technique," Journal of Intelligence and Information Systems, Vol.16, No.3(2010), $99 \sim 120$.

Cho, I. and N. Kim, "Recommending Core and Connecting Keywords of Research Area Using Social Network and Data Mining Techniques," Journal of Intelligence and Information Systems, Vol.17, No.1(2011), 127 138.

FEMA(Federal Emergency Management Agency), Emergency Vehicle Visibility and Conspicuity Study, U.S. Department of Homeland Security, 2009.

Furness, S., J. Connor, E. Robinson, R. Norton, S. Ameratunga and R. Jackson, "Car Colour and Risk of Car Crash Injury: Population Based Case Control Study," British Medical Journal, Vol.327, No.7429(2003), 1455 1456.

Gates, T. J. and H. G. Hawkins, "Effect of Higher-Conspicuity Warning and Regulatory Signs on Driver Behavior," Texas Transportation Institute Report, No. 0-4271-S(2004), Texas A\&M University.
Hawkins, H. G., P. J. Carlson and M. Elmquist, "Evaluation of Fluorescent Orange Signs," Texas Transportation Institute Report, No. 0-2962-S(2000), Texas A\&M University.

Kim, M., N. Kim and J. Ahn, “An Investigation on Expanding Co-occurrence Criteria in Association Rule Mining," Journal of Intelligence and Information Systems, Vol.18, No.1 (2010), 23 38 .

Newstead, S. and A. D'Elia, “An Investigation into the Relationship between Vehicle Color and Crash Risk," Accident Research Centre Report, Monash University, Vol.263(2007).

Shin, S., Y. Rhee, D. Jang, S. Lee, H. Lee and C. Jin, "Relationship Between Car Color and Car Accident on the Basis of Chromatic Aberration', Future Information Communication Technology and Applications," Lecture Notes in Electrical Engineering, Vol. 235, No.1(2013), 45 51 .

$\mathrm{Yu}$, E., J. Kim, C. Lee, N. Kim and S. Jeong, "Predicting the Direction of the Stock Index by Using a Domain-Specific Sentiment Dictionary," Journal of Intelligence and Information Systems, Vol.19, No.1(2013), 95 110. 


\title{
Abstract
}

\section{지능형서비스를 위한 자동차사고와 자동차색깔의 상관관계}

\author{
신성윤 ${ }^{*}$ - 이상원 ${ }^{* *}$
}

지능형 교통 시스템을 설계하는데 있어서, 통신, 외관, 환경, 부수 기능, 안전 등이 반드시 고려되어야 한다. 또한, 자동차를 선택하는데 있어서도, 소비자는 이러한 특성들을 고려한다. 본 논문에서는, 지능화된 교통 서비스를 운영하거나 자동차 구매 의사결정을 하는데 있어서, 자동차 색깔이 자동차 안전에 있어서 매우 중요한 의미를 갖는다는 것을 밝히고자 한다. 자동차 안전과 관련이 있는 자동차 색깔에 따른 자동차 사고 확률에 대해 연구하였다. 그리고, 전진색과 후퇴색의 개념에 대해서도 연구하였다. 전진색은 실제보다 가깝게 보이기 때문에 사고를 적게 유발하지만, 후퇴색은 실제보다 멀리 보이기 때문에 사고를 많이 유발한다. 우리는 자동차 사고 건수를 고려하여, 자동차 색깔을 8 개로 분류하고 이들의 등급을 부여하였다. 또한, 우리의 연구를 실증하기 위해서, 군산에 있는 거주자를 대상으로 전화상담을 통해 조사를 하였다.

Keywords : 지능형교통시스템, 자동차색, 자동차사고, 전진색, 후퇴색, 색수차

* 군산대학교 컴퓨터정보공학과

** 원광대학교 정보전자상거래학부 


\section{저 자 소 개}

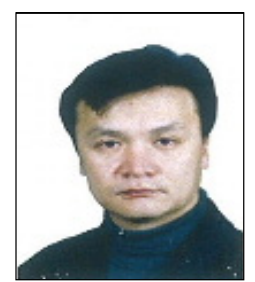

\section{Seong-yoon Shin}

Seong-yoon Shin (the first author) received his Ph.D. degree in Computer Science from Kunsan National University in 2003. Since 2006, he has been working as an associate professor for Kunsan National University. His research interest is computer engineering such as computer vision, image processing, and so on.

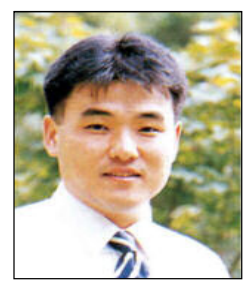

\section{Sangwon Lee}

Sangwon Lee (the corresponding author) received his Ph.D. degree in Management Engineering from Korea Advanced Institute of Science and Technology in 2009. Since 2011, he has been working as an assistant professor for Wonkwang University. His research interest is management engineering such as data engineering, data science, and so on. 